\title{
ЗАРУБІЖНИЙ ДОСВІД РЕГЛАМЕНТАЦІї КРИМІНАЛЬНОЇ ВІДПОВІДАЛЬНОСТІ ЗА ПРОПАГАНДУ КОМУНІСТИЧНОГО ТА НАЦИСТСЬКОГО ТОТАЛІТАРНИХ РЕЖИМІВ
}

\author{
ЛАБА Святослав Володимирович - керівник апарату Франківського \\ районного суду міста Львова \\ DOI:10.32782/NP.2020.2.17
}

Анализируются вопросъ уголовной ответственности за изготовление, распространение коммунистической, нацистской символики и пропаганду коммунистического и начионалсочиалистического (нацистского) тоталитарнъгх режимов по уголовному законодательству зарубежньх государств. На основании анализа предписаний уголовного законодательства отдельных европейских государств констатируются общие и отличительнве черть нормативного урегулирования этого вопроса. Висказивается авторская точка зрения о целесообразности имплементации некоторых положений зарубежного законодательства в отечественное.

Ключевъе слова: тоталитарная идеология, коммунистический тоталитарнъий режим, начионал-сочиалистический (нацистский) тоталитарнъгй режим, пропаганда.

Постановка проблеми

У світі не існує загальноприйнятого кримінального кодексу, який би давав чітку оцінку протиправним діям, що підпадають під категорію злочинів проти миру, безпеки людства та міжнародного правопорядку. Факт існування такого виду світових проблем потребує зосередження на кримінальному законодавстві кожної 3 держав $[1$, c.134]. 3 цими судженнями не можна не погодитися, оскільки вивчення зарубіжного досвіду відкриває перед юристом нові горизонти, дає змогу йому краще пізнати право своєї держави, оскільки специфічні риси цього права особливо виразно прояв- ляються у рамках вивчення інших систем. А тому порівняння здатне озброїти юристами ідеями та аргументами, які не можна отримати навіть за доброго знання тільки власного права [2, с.123-124]. КК України має реформуватися відповідно до стратегії європейської інтеграції з урахуванням найкращих іноземних зразків, оскільки без звернення до іноземного досвіду неможливо розбудувати національну правову систему, зблизити іiі з правовими системами прогресивних держав світу, а відтак забезпечити обмін відповідною інформацією [3, с.24]. Такий досвід, безумовно, є цінним 3 огляду на те, що сприятиме виявленню схожих та відмінних рис кримінального законодавства України та зарубіжних держав, у частині кримінально-правової протидії пропаганді комуністичного та нацистського тоталітарних режимів, а також пошуку найкращих законодавчих зразків, які відповідали б вимогам сучасності та подальше їх впровадження у національне законодавство. Відповідний анахіз також надасть змогу з'ясувати, наскільки ефективними 6 норми, які регламентують кримінальну відповідальність за пропаганду тоталітаризму, що дозволить у майбутньому уникнути ймовірних помилок.

\section{Стан дослідження}

Проблема кримінальної відповідальності за пропаганду комуністичного та нацистського тоталітарних режимів, а відтак оцінки ефективності сучасної кримінально- 
правової заборони, піддавалось аналізу у працях В.М. Комарницького, Е.О. Письменського, М.А. Бабак, А.О.Мостепанюк, А.А. Павловської, О.Е. Радутного, Ю.М. Беклеміщева, О.В. Філей та інших. Водночас доводиться констатувати, що питання кримінально-правових заходів протидії виготовленню, поширенню, а також публічному використанню символіки комуністичного, націонал-соціалістичного (нацистського) тоталітарних режимів «не протоптане»науковцями, оскільки відповідна кримінально-правова норма «отримала право на існування» відносно нещодавно.

Таким чином, основною метою цієї статті є вивчення зарубіжного досвіду регламентації кримінальної відповідальності за пропаганду комуністичного та нацистського тоталітарних режимів.

\section{Виклад основних положень}

Для порівняння слід обрати кримінальне законодавство тих держав, які є членами Европейського Союзу, оскільки «зближення правових систем європейських держав $\epsilon$ найважливішою традицією формування галузей національного законодавства» [4, с.53]. Мова йде про кримінальне законодавство Австрії, Бельгії, Іспанії, Аатвї̈, Литви, Люксембургу, Польщі, Португалії, Угорщини, Франції, ФРН, Хорватії, Чехії. Слід зазначити, що в переважній більшості держав світу відповідальність за вчинення аналізованого посягання відсутня. Приміром, у Сполучених Штатах Америки кримінально-правова заборона пропаганди тоталітарних режимів не регламентується 3 огляду на принцип вільного вираження своїх поглядів, який захищений Першою поправкою до Конституції. Більше того, в американській юриспруденції вважається, що саме лише словесне вираження ідей, поглядів та думок без прямого заклику до насильницьких дій повинно мінімально обмежуватись державою. Як приклад цьому наводиться рішення Верховного суду США 1978 р., за результатами якого суд вважає, що розпорядження місцевої адміністрації, щодо заборони проведення мітингу неонацистів у єврейському кварталі, суперечить
Конституції, з огляду на те, що запланований мітинг не становить собою прямої загрози застосування насильства.

Свого часу у Молдові встановлювалась відповідальність за використання комуністичної символіки у політичних цілях і пропаганду тоталітарної ідеології (з 12 липня 2012 р.), однак Конституційний Суд у своєму рішенні від 5 червня 2013 р. відмінив цю кримінально-правову заборону, так як вона суперечила Основному Закону. Схожа ситуація мала місце і в Угорщині, де уст. 269/В КК була передбачена кримінально-правова заборона поширення, публічного використання чи демонстрування свастики, знаків СС, знаку схрещених стріл, серпа та молота, червоної зірки чи будь-яких символів з їхнім використанням. Водночас не вважалось кримінально-караним використання цих символів в інтересах освіти, науки, мистецтва 3 метою висвітлити інформацію історичних джерел. Втім така заборона проіснувала недовго, оскільки Конституційний Суд 19 лютого 2013 р. визнав їі неконституційною. Можна припустити, що власне підставою для цього слугували дві справи («Вайнай проти Угорщини» та «Фратаноло проти Угорщини»), які розглядались Европейським судом 3 прав людини щодо публічного використання символу червоної зірки. Так, за результатами розгляду справи «Вайнай проти Угорщини» $6 С П \mathcal{\Lambda}$ визнав призначення покарання учаснику демонстрації за носіння червоної зірки у вигляді штрафу порушенням свободи вираження поглядів. На обгрунтування такого рішення ЕСП $\lambda$ зазначив, що, незважаючи на масові порушення прав людини комуністичним режимом, такі його символи, як червона зірка, використовуються як символ міжнародного руху трудівників, які боролися за справедливе суспільство. Окрім того, «потенційна можливість пропаганди комуністичної тоталітарної ідеології не може бути єдиною підставою для заборони використання символів й застосування кримінального покарання... Проста демонстрація чи використання символу особою, навіть членом політичної партії з тоталітарними амбіціями, не може бути прирівняна до небезпечної про- 


\section{Кримінальне право, кримінальний процес та криміналістика}

паганди» [5, с.18]. Водночас у подальшому парламентом Угорщини знову було встановлено кримінально-правову заборону демонстрації, поширення або використання в громадських місцях свастики, значків СС або нілашистського хреста, символів серпа і молота. Втім особа підлягала кримінальній відповідальності за вказані дії лише у випадку, коли така пропаганда здатна порушити громадський спокій, зокрема, людську гідність жертв тоталітаризму або право їх вшанування. Однак, видається, що в будь-якому випадку пропаганда тоталітарних режимів порушує людську гідність їх жертв, а також національну ідентичність громадян, які є нащадками жертв тоталітаризму. У пункті 2 Резолюції Парламентської Асамблеї Ради Европи щодо заходів 3 ліквідації спадку колишніх комуністичних тоталітарних систем від 27 червня 1996 р. № 1096 зазначено, що «тоталітарні режими, які правили в Центральній та Східній Европі в минулому столітті і які все ще перебувають при владі в деяких країнах, всі без виключення характеризуються масовими порушеннями прав людини. Ці порушення розрізняються залежно від культури, країни й історичного періоду. Вони включають окремі і колективні вбивства, страти, загибель у концентраційних таборах, голод, депортації, тортури, рабську працю й інші форми масового фізичного терору».

Зарубіжний досвід регламентації кримінальної відповідальності за пропаганду комуністичного та нацистського тоталітарних режимів засвідчує, що кримінально-караними відповідні дії є лише у кримінальному законодавстві Польщі, ФРН та Угорщини. Водночас кожна з норм, яка встановлює кримінально-правову заборону пропаганди тоталітарних режимів, має свою специфіку. Скажімо, у КК Польщі передбачена відповідальність за публічну пропаганду фашистського чи іншого тоталітарного державного режиму або за заклик до ненависті на грунті національних, етнічних, расових, релігійних відмінностей (ст.256). Як бачимо, у законодавстві Польщі не конкретизовано, за який вид пропаганди тоталітарного режиму особа повинна бути притягнена до кримінальної відповідальності. Однак, видається, окрім фашистського, під цю категорію законотворець також відносить і комуністичний та нацистський режими. Такий висновок випливає з аналізу положень ст.13 Конституції Польщі, де зазначено про заборону існування політичних партій та інших організацій, які у своїх програмах звертаються до тоталітарних методів і прийомів нацизму, фашизму і комунізму.

За КК ФРН кримінально-караними визнається поширення пропагандистських матеріалів партій, які визнані Конституційним судом неконституційними (ч.1 парагр. 86). Окрім того, у п.1 ч.1 параграфу 86а встановлена кримінально-правова заборона поширення на території Німеччини знаків антиконституційних партій, публічне використання їх на зібраннях або розповсюдження їх письмових матеріалів. До таких знаків законодавець відносить прапори, значки, окремі предмети уніформи, паролі і форми вітання. Можна припустити, що мова йде, зокрема, про кримінально-правову протидію пропаганді тоталітаризму. Водночас, ця норма має дещо загальний характер, оскільки законодавцем не конкретизовано, за пропаганду яких матеріалів партій передбачена кримінальна відповідальність. Слід зазначити, що 317 серпня 1956 р. Конституційним судом Німеччини заборонено Комуністичну партію. Таке рішення було прийняте на підставі ст.21 Основного Закону ФРН, відповідно до якої партії, які своїми цілями або поведінкою намагаються завдати шкоду основам вільного демократичного устрою, ліквідувати його або поставити під загрозу, є неконституційними. 3 огляду на зазначене можна зробити висновок, що кримінально-караним визнається пропаганда символіки Комуністичної партії ФРН.

Натомість положеннями кримінального законодавства Австрії, Бельгії, Іспанії, Латвії, Литви, Люксембургу, Португалії, Франції, Хорватії та Чехії не регламентується кримінальна відповідальність за пропаганду тоталітаризму. Щоправда, у Аитовській республіці за поширення і демонстрування комуністичної та нацистської символіки застосовується лише адміністративне покарання (ст.188.18). До такої символіки від- 
несено прапори, герби та емблеми СРСР, Аитовської РСР та нацистської Німеччини, знаки та уніформу нацистської або комуністичної партійних організацій, свастику, знак CC, зображення серпа й молота, радянську червону п’ятикутну зірку. Схоже положення також передбачене у законодавстві Латвії. Зокрема, 20 червня 2013 р. парламентом було ухвалено поправки до Закону «Про безпеку публічних, розважальних та святкових заходів» у якому передбачена адміністративно-правова заборона пропагувати нацистську, фашистську або комуністичну ідеологію, а також використовувати зображення символіки колишнього СРСР, радянські та нацистські прапори, герби та гімни, нацистську свастику (ст.41). Водночас така заборона не є караною у випадках, коли використання такої символіки не спрямоване на виправдання злочинів тоталітаризму чи їх звеличення.

y КК окремих європейських держав передбачена кримінальна відповідальність за заперечення (ст.457-3 КК Аюксембургу, ст.261-а КК Чехії, п.7 ст.607 КК Іспанії, п.3 парагр.130 КК ФРН, ст.240 КК Португахії), оспорювання (ст.457-3 КК Аюксембургу, ст.261-a КК Чехії), виправдання (ст.4573 КК Аюксембургу, ст.261-а КК Чехії, п.7 ст.607 КК Іспанії, п.3 парагр.130 КК ФРН), применшення (п.3 парагр.130 КК ФРН) або схвалення (ст.261-a КК Чехії, ст.15la КК Хорватії) злочинів проти людяності. Зазначені посягання є злочинами з формальним складом, а тому суспільно небезпечні наслідки не передбачені як обов'язковий елемент об'єктивної сторони.

За ст.151a КК Хорватії кримінальній відповідальності підлягає особа за схвалення фашистських, нацистських та інших тоталітарних ідеологій або розповсюдження расизму і ксенофобії. У КК Іспанії вказується на кримінально-правову заборону розповсюдження будь-яким способом ідей або положень, які заперечують або виправдовують геноцид (п.7 ст.607). Цікавими, видаються, положення КК Аюксембургу (ст.457-3), у якому кримінально-караними визнаються заперечення (оспорювання, виправдання) злочинів нацистів, а також фактів геноциду, визнаних люксембурзьки- ми або міжнародними судами або іншими владними органами. Тобто у КК Аюксембургу не йде мова про загальну кримінально-правову заборону заперечення чи виправдання злочинів тоталітаризму, а лише тих, які є офіційно визнаними.

Встановлення кримінальної відповідальності за заперечення, виправдання чи схвалення тоталітаризму у КК зарубіжних держав можна розглядати 3 двох боків. Так, з одного - така кримінально-правова заборона є сумнівною, оскільки відповідні діяння виступають формою вираження поглядів і переконань, що власне відповідає вимогам ст.19 Міжнародного пакту про громадянські і політичні права від 16 грудня 1966 р. (право безперешкодного дотримання та вільного вираження своїх поглядів). А відтак факт заперечення певної історичної події не слід оцінювати як суспільно небезпечний. 3 іншого боку, заперечення, виправдання чи схвалення тоталітаризму не повинні підпадати під захист ст.10 Європейської конвенції з прав людини (щодо свободи вираження поглядів) у випадку, якщо такі дії спрямовані на розпалювання національної ворожнечі або насильства. Про це, зокрема, йдеться у рішенні ЄСП «Perincek v. Switzerland». Так, заявника, який був професором права та керівником Турецької робітничої партії, було засуджено за те, що він неодноразово публічно під час виступів на конференціях заперечував факт масових вбивств та депортацій вірменського народу як геноциду, що мав місце на території Оттоманської імперії у 1915 р. У своєму рішенні $6 С П ~ \lambda$, посилаючись на п.49 Загального коментаря Комітету з прав людини від 29 липня 2011 р., зазначив, що у Міжнародному пакті про громадянські і політичні права від 16 грудня 1966 р. не передбачено загальної заборони за висловлювання помилкових думок чи неправильних інтерпретацій подій минулого. Окрім того, вказав, що у світі немає загального консенсусу щодо визнання подій 1915 р. геноцидом вірменського народу, а тому дійшов висновку щодо несумісності кримінальноправової заборони історичного ревізіонізму з вимогами ст.10 Європейської конвенції з прав людини, зазначивши, що виняток 


\section{Кримінальне право, кримінальний процес та криміналістика}

становлять кримінально-правові заборони заперечення Голокосту, оскільки щодо цих подій є вирок міжнародної судової установи, який постановлений з дотриманням належної процедури [6; 7, с.28].

Таким чином, 3 вищенаведеного можна зробити висновок, що у кримінальному законодавстві не всіх зарубіжних держав законотворець обгрунтовано передбачив кримінально-правову заборону заперечення, виправдання чи схвалення злочинів тоталітарних режимів. Така заборона має належні підстави та є виправданою за наступних умов: 1) якщо має місце заперечення історичних фактів, які визнані як на державному, так і міжнародному рівні; 2) якщо такі дії спрямовані на розпалювання національної ворожнечі або насильства, а відтак суперечать інтересам національної безпеки та є загрозою громадського порядку. Тому, видається, передбачення у кримінальному законодавстві зарубіжних держав загальної заборони заперечення, виправдання чи схвалення фашистських, нацистських та інших тоталітарних ідеологій є хибним кроком законодавця.

Слід зазначити, що в окремих державах були прийняті спеціальні закони, які встановлюють заборону заперечення злочинів тоталітаризму. Так, відповідно до парагр.3 Закону Австрії «Про заборону НСДАП (Націонал-соціалістичної німецької робочої партії)» будь-якій особі забороняється діяти на користь НСДАП або досягати їі цілей, публічно заперечувати, применшувати, схвалювати або виправдовувати злочини націонал-соціалізму. За Законом Чехії «Проти підтримки і розповсюдження порушень прав і свобод людини» від 2001 р. злочинними є дії, які полягають у публічному запереченні, поставленні під сумнів, схваленні або намаганні виправдати нацистський чи комуністичний геноцид або інші злочини нацистів чи комуністів (парагр. 261-а). У Франції в ст.9 Закону «Про придушення актів расизму, антисемітизму та ксенофобії» (Закон Гейссо) від 13 липня 1990 р. передбачена заборона заперечення Голокосту, а також висловлювання сумнівів в існуванні таборів смерті і газових камер, у яких нацисти здійснювали масові вбивства. Від- повідно до ст.1 Бельгійського Закону про заборону Голокосту від 23 березня 1995 р. кримінальній відповідальності підлягають особи, які заперечують, виправдовують або схвалюють геноцид німецького націоналсоціалістичного режиму під час Другої світової війни.

Наступне питання, яке необхідно розглянути, стосується караності аналізованих злочинів. Так, відповідно до ст.256 КК Польщі, за пропаганду фашистського або іншого тоталітарного режиму передбачене покарання у виді штрафу, обмеження волі або позбавлення волі на строк до двох років. За КК ФРН позбавленню волі строком до трьох років або грошовому штрафу підлягає особа за поширення на території $\mathrm{Hi}$ меччини знаків антиконституційних партій, публічне використання їх на зібраннях або розповсюдження їх письмових матеріалів (п.1 ч.1 параграфу 86а).

За заперечення, виправдання чи схвалення злочинів тоталітаризму передбачене покарання у виді позбавлення волі на строк до трьох років (ст.216 КК Угорщини), до п'яти років (ст.240 КК Португалії, п.3 парагр.130 ФРН), від шести місяців до трьох років (парагр.261а Закону Чехії «Проти підтримки i розповсюдження порушень прав і свобод людини»), від одного до двох років (п.7 ст.607 КК Іспанії), позбавлення волі до одного року та штраф у розмірі 5 тисяч франків (ст.1 Бельгійського Закону про заборону Голокосту). Найбільш сувора міра покарання передбачена за законодавством Австрії - позбавлення волі строком від одного до десяти років (парагр.3 Закону Австрії «Про заборону НСДАП (Націонал-соціалістичної німецької робочої партії)». Такий підхід, видається, є не до кінця виваженим, оскільки законодавець встановив надмірно великий розрив між верхньою та нижньою межею санкції, що власне створює широкий простір для суддівського угляду. Для прикладу, санкція зазначеної статті прирівнюється до санкції за нанесення тілесного ушкодження, що спричинило смерть потерпілому (парагр.86 КК Австрії).

Незважаючи на значущість суспільних відносин, на які здійснюеться посягання як пропаганда тоталітарних режимів чи 
заперечення їх злочинів, доводиться констатувати про відносно невелику кількість випадків притягнення до кримінальної відповідальності за їх вчинення. У різних куточках світу за вказані дії було засуджено кілька десятків осіб (австрійський письменний Герд Хрнзик - за заперечення Голокосту і пропаганду нацизму; редактори неонацистського інтернет-видання Эрик Садлачек і Либор Будик - за розповсюдження неонацистської пропаганди і заперечення Голокосту; французький письменник Робер Фаріссон - за оспорювання того, що фашисти в Освенцимі вбивали людей у газових камерах; Володимир Створа - за розміщення на своєму інтернет-сайті перекладу на чеську мову статті, яка заперечує Голокост; політик Жан-Марі Лепен - за виправдання гестапо і заперечення злочинів проти людяності; британський єпископ Ричард Вільямсон - за заперечення Голокосту у своєму інтерв'ю [8, с.888; 9, с.259].

\section{Висновки}

Таким чином, вивчення зарубіжного досвіду регламентації кримінальної відповідальності за пропаганду комуністичного та нацистського тоталітарних режимів дає змогу зробити наступні висновки. Невдалими видаються положення кримінального законодавства тих держав, у яких встановлена загальна кримінально-правова заборона заперечення, виправдання чи схвалення фашистських, нацистських та інших тоталітарних режимів. Не вартим для запозичення $є$ також досвід кримінального законодавства Австрії, у якому передбачена надмірно сувора міра покарання за заперечення злочинів націонал-соціалізму (від одного до десяти років позбавлення волі), що руйнує сутність правосуддя. У цьому випадку слушними $є$ міркування В.О. Навроцького, який наголошує на тому, що несправедлива критика КК України, протиставлення його законодавству зарубіжних держав, де нібито все краще та досконаліше, видається безпідставною, оскільки основною проблемою в цій галузі на сьогодні - це не недоліки кримінального закону, а його неправильне застосування чи незастосування на практиці [10, с.50]. \ітература

1. Торош С.О. Злочини проти людства та правові механізми їх врегулювання. $T e$ орія і практика конституиіоналізму: українсъкий та зарубіжний досвід: матеріали першої науково-практичної конференції, 30 квітня 2015 року, Аьвів / Національний університет «Аьвівська політехніка», Навчально-науковий інститут права та психології, Кафедра конституційного та міжнародного права. - Аьвів, 2015. С.134-139

2. Ансель Марк. Методологические проблемы сравнительного права. Очерки сравнительного права. - М.: Прогресс, 1981.C. $36-86$.

3. Савченко А. В. Порівняльний аналіз кримінального законодавства України та федерального кримінального законодавства Сполучених Штатів Америки: автореф. дис. на здобуття наук. ступеня д-ра юрид. наук: спец. 12.00.08. К., 2007. 36 с.

4. Тацій В. Я., Грошевий Ю. М. Проблеми зближення європейських правових систем як умова гармонізації законодавства України. Проблеми гармонізації законодавства Украйни з міжнародним правом: матеріали науково-практичної конференції. К., 1998. C. 53-54.

5. Рябенко С., Когут А. Европейські законодавчі практики декомунізації: висновки для України. Аналітичний звіт / Центр досліджень визвольного руху. Аьвів: «Часопис», 2017. 52 с.

6. Перінчик проти Швейцарії «Perincek v. Switzerland». [Електронний ресурс]. URL: https://cedem.org.ua/library/perinchek-protyshvejtsariyi-vp-perincek-v-switzerland/

7. Задоя К. П. Правові позиції Європейського Суду з прав людини щодо кримінально-правових обмежень права на свободу вираження поглядів. Адвокат. 2014. № 2. С. 27-29.

8. Дудоров О.О., Хавронюк M.I. Кримінальне право: Навчальний посібник / За заг. ред. М.І. Хавронюка. - К., 2014. $944 \mathrm{c}$.

9. Варченко И.А., Аитвяк А.Г. Уголовное законодательство зарубежных стран об ответственности за преступления, аналогичные ст.354.1 УК ПР «Реабилитация 


\section{Кримінальне право, кримінальний процес та криміналістика}

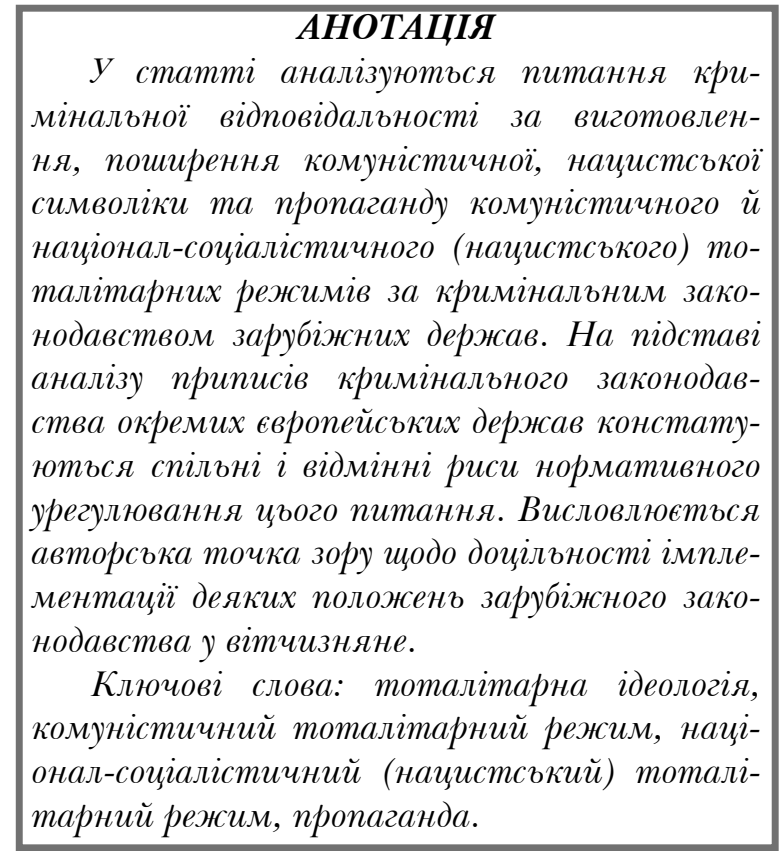

нацизма» (Часть 2). Гуманитарнъле, соииально-якономические и общественнъие науки. №11. 2015. Часть 1, 2, 3 . С.257-260
This paper examines the international experience of regulation of criminal responsibility for production, distribution communist, Nazi symbols and propaganda of the Communistic, Nationalistic and Socialistic (Nazi) totalitarian regimes. On the basis of analysis of orders criminal legislation separate European countries the general and excellent lines of the normative regulation this question. The author point of view speaks out in relation to expedience of implementation of some positions of foreign legislation in domestic practice.

Key words: totalitarian ideology, the Communistic totalitarian regime, the Nationalistic and Socialistic (Nazi) totalitarian regime, propaganda.

10. Навроцький В.О. Кримінальне законодавство зарубіжних держав: [питання особливої частини] / Аьвів: юридичний факультет Аьвівського державного університету ім. Івана Франка, 1999. 56 с. 